\title{
UNCONVINCED, UNRECONSTRUCTED, AND UNREPENTANT: A REPLY TO PROFESSOR FRIEDMAN'S RESPONSE
}

\section{H. RICHARD UVILLER $\dagger$}

How does one maintain the requisite fire for a proper academic quarrel with a man who first quotes his wife's disparaging judgment and follows with a reassuring footnote citation to the birth certificate of his daughter? ${ }^{1}$ I am altogether disarmed.

My second problein (and this is not its first manifestation) is how to respond to an adversary who claims "rigorous and precise analysis" on his side? ${ }^{2}$ The claim has a familiar ring. Like the invading law and econormics crowd a decade ago, these Bayesians hint that those of us who reason in prose are academic slobs, our pedagogical shirttails out, our logical shoelaces untied. Reformulating familiar propositions as theorems, recasting intelligible arguinents as esoteric formulae, they claim to be sprucing up legal discourse. It's vaguely insulting. But what can we storytellers and inferentialists say: loose-jointed reason is better than analytic rigor? We can hardly write responses to their little Bayesian puzzles offermg to introduce soine slack into their rigid regimes. Still, I can't help but think that wandering down the wondrous byways of an untamed idea is probably no worse than inarching in formation across the inodeled turf of the drill field.

The claim of the rigorous precisionsts is not, as the uninitiated might suppose, that the Bayesian theorems offer the factfinder a better means of calculating probability than is customarily performed by the ordinary, crude sense of likehihood. They do not suggest that juries or judges would ever use these esoteric formu-

$\dagger$ Arthur Levitt Professor of Law, Columbia University.

1. Whether the spousal comment is cited with pride or humility is hard to say; the procreation is expressly offered to prove the marriage thrives. See Richard D. Friedman, Character Impeachment Evidence: The Asymmetrical Interaction Between Personality and Situation, 43 DUKE L.J. 816, 817 n.4 (1994).

2. "Bayesian logic, which [Uviller] does not use, helps to make probabilistic analysis more rigorous and precise." Id. at 818. 
lae or even reason along these lines. They firmly disavow any proposal that numerical values be attached to their variables and a mathematical calculation performed. ${ }^{3}$ But if the exercise does not produce a mathematical result and no judge or jury would ever think along the lines described, wherein lies the virtue of rigor in the analysis? ${ }^{4}$

I appreciate Professor Friedman's gentle exertions to persuade me that I am, at heart, a good Bayesian, that my clumsy thoughts reveal the seeds of more refined cogitation. ${ }^{5}$ It is certainly not surprising to ine that two travellers agree on many points along the trail of logic and common sense. I do not think, however, that the measure of my acuity is its fit with Professor Friedınan's preferred mode of thinking, ${ }^{6}$ rather, I think that the reason the ghost of the Reverend Bayes still haunts us alınost 250 years after the good preacher's demise is that the "analysis" of Bayesian acolytes accords with the careful reasoning of the rest of us.

While I am grateful for Professor Friedinan's welcome to the Bayesian Club (albeit as a novice in need of some indulgent in-

3. "[T]here is nothing," Professor Friedman now insists in a charming disavowal, "formulaic, or numerical, or even particularly complicated, about the Bayesian analysis needed for a basic understanding of character impeachment evidence." Id. at 818 (citing Richard D. Friedman, Character Impeachment Evidence: Psycho-Bayesian [1?] Analysis and a Proposed Overhaul, 38 UCLA L. REv. 637, 692-97 (1991)). I quote a typical statement from the several pages of the same sort of thing in the Appendix to Professor Friedman's earlier submission: "P(NOT-TEST(EXCULP)/O, EXCULP) $=.8$." Id. Who could call that statement formulaic, numerical, or anything but simple? In a footnote, Friedman concedes that "some simple mathematical probabalistic analysis" and a couple of diagrams were presented in his Appendix, but these, he assures us, "were by no means essential to the argument." Friedman, supra note 1 at 818 n.11. By extension, I would suggest that the entire recourse to Bayes was by no means essential to a meamingful discussion of the effects of certain kinds of impeachment evidence on credibility.

4. I should probably not discount the virtue of academic entertainment. Plus, leadmg law reviews do publish this sort of thing; I think law students dig it as harder-edged thinking than the old fashioned discussions of relevance and prejudice. Westlaw's database for journals and law reviews lists 213 entries containing the word "Bayes" or "Bayesian" and six with one of those words in the title. Search of Westlaw, TP-ALL database (Nov. 30, 1993).

5. "[T]he key elements of the [analytic approach of the Friedman article] may be found in [Uviller's] own Article." Friedman, supra note 1, at 816.

6. I think Professor Friedman is slyly suggesting that I am on to something by noting the many points at which my Comment accords with his reasoning. Perhaps not. These notations may be merely a gracious way of seeking peace between us. On this assumption, I must say the tactic has worked well. I am far more peacefully disposed than I would have been had I been confronting an antagonistic rejoinder. (I'm sure this sentiment too can be couched in Bayesian logic, but I am not so well-disposed as to give it a try.) 
struction), I have the uncomfortable feeling that our accord may be illusory. We may be using the same words but talking at cross purposes. It is certainly true that, like Professor Friedman and the Bayesians, I speak in terms of the probabilities. Everyone concerned with the epistemological tenets of the law of evidence does. However, I think I may be using the term in a somewhat different sense than a logical probabahist would. I use likehhood not as a predictive ratio but, as a historian might, to express the degree of certainty $I$ feel that an event did or did not happen. To say it is highly probable that Booth shot Lincoln is not quite the same as saying it is highly probable that the temperature on a randomly selected day in January will be below fifty degrees Fahrenheit or that the probability of drawing an ace on the first cut of the deck is very low. These latter probabilities can be calculated on the basis of numerical data: the number of cold days in previous Januaries, the number of aces and other cards in the deck, etc.

But in the former case, all we are saying is that we are reasonably certam that the fact is true. The data for this assertion are quite different; they are not derived by counting the ways things might turn out or toting up unrelated prior occurrences of the same sort. Rather, historical probability considers traces of the event in issue and attempts to reconstruct the event that produced thein. When we liave finished, we say, "Most probably, this is what happened" to signify our high level of certainty of behef. A formal coinputation of probability does not work that way.

So I think Friedman may be mistaken concerming the overlap in our thinking. My own level of certainty on this proposition is low, however, because, for all their efforts at formal rigor, Bayesians often sound as though they too are concerned with historical ratler than logical "probability".

\section{GRATUITOUS BAYESING}

Professor Friedman divides his brief into two points. ${ }^{7}$ In the first, he gives us yet another patient, entry-level description of the basic structure of the Bayes Theorem applied, this time, to the utility of evidence of bad character on the issue of the credibility

7. He claims the piece has three parts, but I count only two. See Friedman, supra note 1 , at 817 . His third part is mainly a claim to the virtue of simplicity. But a rule of discretionary character impeachment in both directions is as simple and holds the same promise for general judicial comprehension. 
of a testifying witness. In this Part, I think he and I differ mainly on the work the Bayesian approach does in the determination of credibility and on the role of impeachment in that process. To me it seeins that Bayesians generally (and, apparently, psychoBayesians along with them) present propositions, chopped into logical pieces (as their mentor advised), arriving at a series of conclusions that are either unremarkable or unintelligible. ${ }^{8}$ And specifically, in his reliance on the old preacher's formulations, Professor Friednian is required to load his implements with assumptions concerning the very propositions to be proved: the credence to which a particular witness is entitled. I ain sure I will have no greater success convincing Friedman than he has had with me, but I too will try at least one gambit to that end.

Pointing out that two of his critical three factors in the Bayes formulation are the probability of a witness telling the truth and the probability of the witness lying, ${ }^{9}$ Professor Friedman professes mystification at my statement that he assumes credibility out of his schenia. ${ }^{10}$ I certainly do not so deeply misunderstand Friednian's thesis as to say it is not related to credibility. Rather, I say that the model ignores the central credibility issue. The nuain problen is not the probability that a hypothetical witness (or the defendant) is lying, but the guides available to a human judge to determine whether a particular witness (or defendant) is in fact lying in a given instance.

When he coines to consider a particular witness, Friednian chooses a defendant and assumes that the defendant is guilty and therefore highly likely to lie. ${ }^{11}$ That assumption removes the cen-

8. As an example of the former, I call attention to his footnote 14. There, the "crucial proposition ... central to the case" is stated thus: "[I]f the defendant's exculpatory story is true, he is innocent . . . " Id. at $820 \mathrm{n.14}$. Another example of the ho-hum is the observation that the evidence of the defendant's incredibility does not affect the "first probability assessinent," which is posited as the probability of guilt independent of the defendant's testimony. Id. at 821. For an example of the latter, see supra note 3 .

9. Friedman identified three "elemental probabilities:"

(1) The probability of innocence as assessed without regard to the defendant's testimony.

(2) The probability that the defendant would testify as he has assuming the testimony is true-that is, assuming he is innocent.

(3) The probability that the defendant would testify as he has assuming the testimony is false-that is, assuming he is guilty. Friedinan, supra note 1 , at 820 .

10. Id. at 819 .

11. Id. at 823,825 . 
tral problem of assessing credibility-deciding who is lying about what. The assuinption is required because Bayes's theorem can tell us nothing of the likehiliood that a particular witness is lying. Of course, Professor Friedman is not so enamored of the seductive simplicity of his inodel that he does not realize that lie is putting the rabbit in the hat. "[W]e are," he acknowledges, "already assuming liypothetically an important fact about the defendant personally: that he is guilty of the crime charged."12 That assuinption, he continues, is "at least suggests" that the defendant may he to escape conviction. ${ }^{13}$

Explaining his use of Bayes's theory, Friedman comes down to what lie calls the "third probability assessment,"14 that is, the probability that a guilty criminal defendant would give exculpatory testimony. "Careful analysis," he says, will show that characterimpeaching evidence will have little effect on this assessment. ${ }^{15}$ Obviously. Even careless analysis should inform us that a guilty defendant is very likely to give exculpatory testimony if he chooses to testify-regardless of his character. ${ }^{16}$

The problem is witl the assumed hypotheses of both this probability assessment and the "second probability assessment:" how is the jury to know whether the hypothesis of guilt or of innocence is more likely to be accurate? Here, Friedinan appears to abandon the rigor of his trifurcated formulation, saying that "[t]he question ... coines down to whether character inpeachment evidence will help substantially in showing that the defendant is willing to make an exculpatory statement under oath."17

12. Id. at 827 .

13. Id.

14. Id. at 823 .

15. Id.

16. Professor Friedman's "peek ahead" at this Reply has generated a seven-paragraph footnote laden with regret at the obstinate and persistent "misunderstandings" of those (like his wife and me) who disagree with him. See id. at 825 n.33. From the other side of the "great intellectual divide," I here content myself with only one riposte (but muse on whether he will yield again to the temptation to peek and reply and, if so, whether-like Zeno's crawl-this game can continue infinitely). I do say here that even careless analysis tells us that a guilty defendant will he if he testifies-a guilty defendant, Professor Friedman. What character evidence shows (if indeed it shows anything at all) is that the defendant is in fact guilty/lying, not that he is "substantially more likely to lie if he is in fact guilty," as he puts it. Id. (emphasis added). I pull these two sentences out of Professor Friedman's long footnote 33 only because I think they illustrate his regrettable "misunderstanding" of my point.

17. Id. at 823 . 
As put, the question seems meaningless to me: all defendants are willing to swear to an exculpatory story. I think what Friedman must mean is that the question comes down to whether the defendant's exculpatory story is true or false. Which is another way of asking whether the defendant is guilty or ininocent, since we can assume that most ininocent defendants tell true exculpatory stories, whereas the guilty lie. ${ }^{18}$

This distinction is, indeed, what the question comes down to-as any non-Bayesian could have told Professor Friedman at the start, thereby saving him (and the rest of us) a good deal of meaningless introductory rigor. It is significant, I think, that when Professor Friedinan addresses this crucial question, there is scarcely a trace of the good Reverend Bayes. He says, "I believe . . .," calling on some unarticulated principle of faith, and then quotes $m e$, hardly a source in the Bayesian mode. ${ }^{19}$ The significance I attach to this passage is that it demonstrates that, in the crunch, Father Bayes is useless. Further along, as I read him, Friedman admits as inuch when he says, "The hypothesis of the crucial probability assessinent ... does not help; it tells us nothing, even hypothetically, about the witness's personality or character or inchination to tell the truth."20

\section{THE ASYMMETRICAL TILT}

Our quarrel over method seeins to be relatively good-natured since it expresses little more than different styhistic preferences in academic discourse. The meat of our disagreenent is in the outcome, what Professor Friedinan rather pretentiously calls, "an Asymmetrical Solution."21 (Presumably, this is the promised "sweeping reforın" of his orignial piece.)

Friedinan starts with the dubious premise that all defendants have "an extremely powerful incentive to he."22 This assertion must stem from an inadvertent assumption that all defendants are

18. I take it Friedman agrees. In his "second probability assessment," he notes that the probability is "very high" that an innocent defendant will give exculpatory testimony-regardless of his character. Id. at 822 .

19. Id. at 823 (quoting $\mathrm{H}$. Richard Uviller, Credence, Character, and the Rules of Evidence: Seeing Through the Liar's Tale, 42 DuKE L.J. 776, 813 (1993)).

20. Id. at 827 .

21. Id. at 825 .

22. Id. 
guilty. And it informs his conclusion that, given the jury's recognition of their high induceinent to lie, testifying defendants (unlike other witnesses) do not require impeachment by evidence of their bad character. ${ }^{23}$ Friedman not only ignores that sinall segment of accused defendants who, as innocent people, have a high incentive to tell the truth, he forgets the high proportion of jurors who take seriously the adinonition to "presume" innocence and consider the defendant innocent until convinced otherwise.

Professor Friedinan claims to be baffled by niy coniment: "Who can quarrel with Friedman's thesis that where the jury is operating on the assumption that the accused is guilty, the prosecution need not resort to an attack on credibility through evidence of bad character?"24 Still, it seeins to nie this is the heart and essence of his asymmetrical solution. In his own (niost recent) words on the subject: "Second, by the hypothesis governing this probability assessnient, the defendant is guilty of a crime-the one charged. Evidence of other misconduct tending to show bad character will therefore tend to be cumulative."25 This statement, he argues, does not niean the jury approaches the case with a presumption of guilt. I do not suggest that it does. What it does niean (I think) is that, regardless of the court's instruction on the presumption, the jury will tend to put the accused in the "third category" (that is, consider him guilty) when they hear the evidence against him and therefore assuine that his testimony is false. This assumption (not to be confused with a presuinption), which Professor Friedman prefers to call a high probability assessment, renders the character evidence superfluous. This statement is no different, I think, froin the one I ascribed to him.

I do not know why Professor Friedinan insists on the proposition that because the prosecutor is trying to show that the defendant committed the charged crime ("put him in a bad light" is the way he expresses it), ${ }^{26}$ she has no need of the evidence of the defendant's bad character. ${ }^{27}$ Obviously, if character evidence has any function at a trial at all, it is to assist the jury in determining

23. See id. at 832-33.

24. Id. at 824 (quoting Uviller, supra note 19, at 830) (alteration omitted).

25. Id. at 823 .

26. Id. at 830 .

27. See, e.g., id. ("E $[\mathrm{v}]$ ven without character impeachment evidence, the prosecution will do its best to put him in a bad light by trying to show that he cominitted the crime charged."). 
whether the defendant is telling the truth when he asserts that he does not deserve the bad light in which the prosecution is trying to put him. The prosecutor's efforts to put him in that light do not substitute for evidence of whether the defendant belongs there.

In a sense, I suppose, Friedman's approach has merit. Most criminal defendants are in fact guilty, so the probability is that they will lie if they give exculpatory testimony. Most, but not all. The problem, I am beginning to suspect, with probabihists is that, in dealing witl probabilities, they are necessarily considering the universe - of crimmal defendants, in this case-and so the most probable fact is taken as the representative fact. Jurors, on the other hand, must take the world one item at a time. It makes no difference to them that nine out of ten defendants are guilty because that datum does not really lielp thein to know whetlier the case before them is one of the nine or the tentl.

The essence of the Friedman position (which I found repugnant) is his acceptance of the proposition that a "witness's cliaracter for truthfulness"28 (by whicl, I assume, lie means not only his criminal record but also evidence of unprosecuted misdeeds) is "lielpful" to a jury and slould be admitted-but only if the witness is not the defendant testifying in his own behalf. ${ }^{29}$ First, as I attempted to deinonstrate-alas, not persuasively to Professor Friedman-there is considerable doubt just low lielpful evidence of this sort really is. ${ }^{30}$ Witliout replaying iny argument here, let me say only that, in the way I read liuman nature, a prior conviction-even for a crime mvolving dishonesty, like passing a bad clieck-lias relatively little bearing on testimomial mendacity. One's stake in liaving the false tale believed and the estimated persuasiveness of the lie I count as the primary determinants of the decision to lie on the stand, determmants so powerful that previous criminal beliavior is like a candle in a halogen beam.

28. Id. at 821.

29. Professor Friedman puts it with the sort of charming naivete that hints that, without the aid of Bayes, he might occasionally fail to apply his touted analytical rigor to legal cliches. "[C]haracter impeachment evidence" (remember, we are talking about prior convictions and such), Friedman says, might "strongly suggest[] that the witness is a person who, with relative alacrity, would ignore her social obligation to tell the truth under oath." Id. at 828. In concrete terms, Friedman says that evidence that a man was convicted five years before of car theft might strongly suggest that the witness would lie with alacrity when he testifies that he saw two men run out of the saloon after the shooting, get into a blue car, and speed away.

30. See Uviller, supra, note 19. 
Second, Professor Friedman returns to the "prejudice to the defendant" standard of admissibility which I had thought (with rehef) had been written out of the Federal Rules of Evidence in recognition of the fact that prejudice is a two-way street. ${ }^{31}$ We do not need help from the good Dr. Bayes to appreciate that, under impeachment by evidence of prior misconduct, a defendant suffers a special chill on his right to testify plus heightened dangers of misapplication of character evidence (to the forbidden inference of propensity). Nor is this a discovery of Friedman's (although at times, he leads one to think it might have been). Elimination of this disability is the heart of Friedman's "sweeping reform," though to me it seems more like the revival of a discredited standard.

Of course, under the general prejudice standard of the revised Federal Rule, the defendant's special claims to prejudice are considered (and are often dispositive), as when, for example, courts delete impeachment references to prior convictions of crimes similar to the one on trial. But the proposition on which our postreform reformer remains unconvinced is that prejudice is conceivable-imdeed, prejudice that outweighs the dubious probative value of character-against the prosecution. Perhaps the simgle example that stands the best chance of shakmg Professor Friedman's stance is the admission of a rape complainant's prior conviction for prostitution. My next shot would be allowing the impeachment of the victim of alleged police brutality with a prior conviction for resistmg arrest. Am I playing to Friedman's weak side? I know not. The jerk of the "left knee" is his image not mine. ${ }^{32}$

I do not, as Professor Friedman seems to think, "fear[] leavmg the matter [of assessing prejudice] to judicial discretion."33 I do have considerable doubt that character evidence is probative of credibility and I do suggest that if the character impeachment of prosecution witnesses is to be at the mercy of judicial discretion, defendants should be im a position of comparable hazard. ${ }^{34}$

I suppose Professor Friedman's claim to "political imcorrectness"35 may derive some support from his rather grudging ac-

31. See Friedman, supra note 1 , at 827 n.35; Uviller, supra note 19, at 817-20.

32. See Friedman, supra note 1 , at 829.

33. Id. at 828 (citing Uviller, supra note 19 , at 829 ).

34. Uviller, supra note 19 , at $829-30$.

35. Friedman, supra note 1 , at 829 . 
knowledgement that a rule barring absolutely the impeachment of the defendant by evidence of prior conviction might undercut the main rationale supporting Griffin v. California. ${ }^{36}$ Although his acceptance of this consequence might antagonize some who would otherwise count Friedman a friend, I thought it to be of little significance on an insignificant point. If anything, Friedman's overhasty relimquishment of this important doctrine reveals less of his political leaning than of his casual approach to constitutional theory. With a hittle further thought, he imight have found considerably more to support this intriguing example of the jurisprudence of Justice William $O$. Douglas than its obvious connection with the conviction-encumbered defendant's choice to remain off the stand. Comment on a defendant's failure to testify is equally unconstitutional, Friedman might have noted, when the defendant has no prior convictions, or when they have been excluded by judicial order. That aspect of the rule might carry an argument for its survival despite the Friedman "Reform."

Finally, I must dismiss as hittle short of whimsical Professor Friedman's "so what" argument that, because the criminal process contams a number of unrelated "asymmetries" favoring defendants, it can tolerate a differential rule on character impeachment. ${ }^{37} \mathrm{He}$ knows this is not a "sufficient" argument for this proposal; still he thimks it weighty enough for mention. But silly argument weakens the poimt it intends to support. Not much more persuasive is his plea that a true and universal difference in the probity-prejudice balance would justify asymmetrical rules. ${ }^{38}$ It is not the conclusion but its premises that require more convincing arguinentation than Friedman has provided.

So in sum, I must report myself unpersuaded by Professor Friedman's brief. I cannot join the ranks of Bayes's champions, psycho or otherwise, and I continue to find Friedman's asymmetrical solution unattractive. ${ }^{39} \mathrm{I}$ am, however, pleased by Friedınan's

36. Id.; see Griffin v. California, 380 U.S. 609 (1965).

37. Friedman, supra note 1 , at $830-31$.

38. Id.

39. Professor Friedman suspects that I do not understand his argument and suggests that, if I paid attention ("focused more closely" is the gentle way he puts it), I would like it ("find it more palatable than he recognizes"). Id. at 816. His optimism, I fear, is more a measure of his confidence than of the merits of his thesis. I am sorry to disappoint him, but I think I have focused on his idea as sharply as I can and done my best to understand, but my palate still rejects the fare. 
careful and generous attention to my comment on the troublesome element of credence im the process of adjudication. ${ }^{40}$

40. P.S. to Joanna Friedman: Mazel tov on the birth of Rebecca Abigail. See id. at 817 n.4. It proves again that there are more important compatibilities than intellectual. Sorry to hear of your "strategic surrender," see id. at $817 \mathrm{n.5}$, but I subscribe to the old maxim: "A person convinced against her will is of the same opinion still." So, please Joanna, don't disband your guerrilla forces. 